\title{
Spawning synchrony and aggregative behaviour of cold-water echinoderms during multi-species mass spawnings
}

\author{
John H. Himmelman ${ }^{1, *}$, Clément P. Dumont ${ }^{1,2}$, Carlos F. Gaymer ${ }^{1,2}$, \\ Catherine Vallières ${ }^{1}$, David Drolet ${ }^{1}$ \\ ${ }^{1}$ Département de Biologie, Université Laval, Québec City, Québec G1K 7P4, Canada \\ ${ }^{2}$ Center for Advanced Studies in Arid Zones (CEAZA), Departamento de Biologia Marina, Universidad Catolica del Norte, \\ Larrondo 1281, Casilla 117, Coquimbo, Chile
}

\begin{abstract}
Although many marine invertebrates reproduce by releasing gametes into the water, major spawning events have rarely been observed for cold-water invertebrates. We documented mass spawnings by the sea star Asterias vulgaris and the ophiuroid Ophiopholis aculeata on 6 July 1996 and 2 July 1998, and by these 2 species plus a second ophiuroid Ophiura robusta and the sea urchin Strongylocentrotus droebachiensis on 3 July 2003. In each year, the abrupt spawning events coincided with the first major intrusion of warm surface water into a region normally dominated by cold upwelling. The behaviours of the ophiuroids and sea stars favoured fertilization success. First, they spawned from elevated surfaces, with the central disc raised, to increase suspension and mixing of gametes. Second, many individuals pseudocopulated, which involved crawling over one another in the case of the sea star, and individuals holding their central discs together in the case of the 2 ophiuroids. Models of fertilization success need to incorporate such behaviours to better understand fertilization in the sea.
\end{abstract}

KEY WORDS: Ophiopholis aculeata - Ophiura robusta $\cdot$ Asterias vulgaris $\cdot$ Strongylocentrotus droebachiensis · Mass spawning · Behaviour · Pseudocopulation · External fertilization · Northern Gulf of St. Lawrence

\section{INTRODUCTION}

The most common reproductive mode of marine invertebrates involves the release of gametes in the water (Thorson 1946). Theoretical models show that high densities of eggs and sperm are critical to fertilization success, and sperm limitation can therefore be severe unless numerous individuals spawn simultaneously (Levitan \& Petersen 1995, Yund 2000). The proximity of spawning individuals can also enhance fertilization success, but factors such as strong water movement can reduce success (Levitan \& Petersen 1995, Denny et al. 2002, Yund \& Meidel 2003).

For many invertebrates, we know the approximate times of spawning from changes in gonad size or con- dition, but most studies only sample at monthly intervals, due to the effort required to collect and dissect animals (Himmelman 1999). Thus, the exact time and duration of spawning is unknown. To identify spawning cues sampling must be done at much greater frequency (weekly or less), and there should also be continual or daily measurements of environmental factors (Bonardelli et al. 1996). Fertilization assays sensu Gaudette et al. (2006) provide an interesting alternative approach for documenting the timing and intensity of spawning observations.

Field observations of gamete release by large numbers of individuals clearly indicate major spawning events. The first well-documented mass spawnings were for the crinoid Comanthus japonicus in southern 
Japan (Kubota 1980) and for the palolo worm Eunice viridis in the Samoan Islands (Caspers 1984). Subsequently, multi-species mass spawnings have been documented for many sessile tropical species (corals, anemones and sponges) that spawn at a predictable time in coordination with environmental rhythms (Harrison et al. 1984, Babcock et al. 1992). In contrast, there are surprisingly few reports of major spawning events for temperate and cold-water invertebrates. The reports most clearly indicating synchronous spawning by large numbers of individuals are probably those of Minchin (1987, 1992), Breen \& Adkins (1980), Sewell \& Levitan (1992) and Hamel \& Mercier (1996). The scarcity of such observations, due to their short duration and unpredictable timing, greatly limits our understanding of fertilization dynamics. In particular, we know little about how animals behave during major spawnings. Strong selective pressure to adopt behaviours that enhance fertilization success would be expected. Most reports of spawning behaviours are based on incidental spawnings of a few individuals.

The aim of the present paper is 3-fold: (1) to report rare spawning events involving
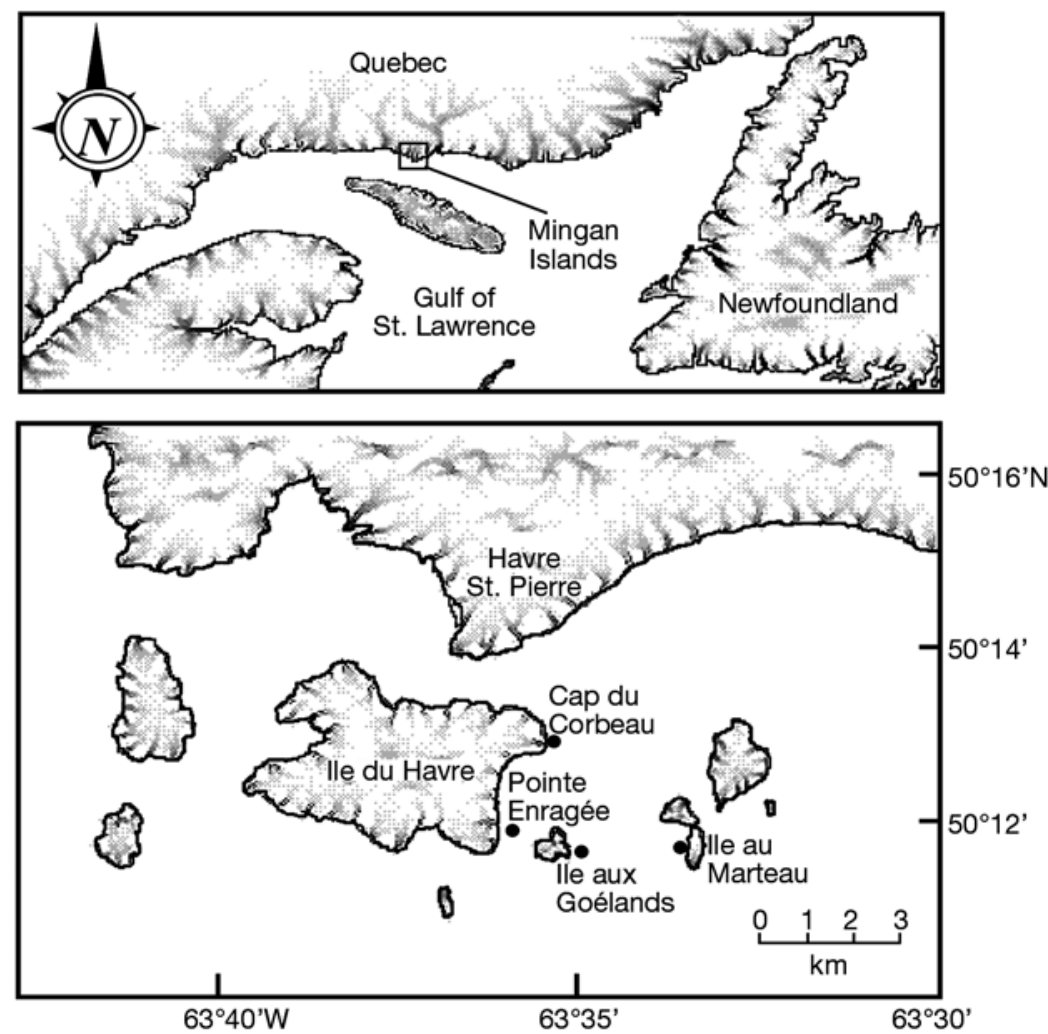

Fig. 1. Map of the Mingan Islands, northern Gulf of St. Lawrence, showing locations of mass spawning events mass multi-species spawnings of cold-water echinoderms; (2) to consider environmental factors that potentially triggered these highly synchronized events; and (3) to describe behaviours during spawning, including rapid aggregation and pseudocopulation, which likely enhanced fertilization success.

\section{MATERIALS AND METHODS}

Our observations were made during the course of ecological studies of sea stars (Gaymer et al. 2001, 2002 Raymond et al. 2007), sea urchins (Dumont et al. 2006, $2007 \mathrm{a}, \mathrm{b}$ ) and ophiuroids (Drolet et al. 2004a,b) off the Mingan Islands in the northern Gulf of St. Lawrence, eastern Canada (Fig. 1). We regularly dived $>2 \mathrm{~h}$ per day from June through August each summer and encountered mass spawning events during dives in early July in 1996, 1998 and 2003 (Table 1). When this occurred, we focused on noting the numbers of individuals spawning and spawning behaviours. Most observations were made at 7 to $12 \mathrm{~m}$ depth within the urchin barrens zone (with patches of the grazing resistant brown algae Agarum clathratum and Desmarestia viridis), where the density of adults was $>80 \mathrm{~m}^{-2}$ for the 2 ophiuroids Ophiopholis aculeata and Ophiura ro- busta, about $50 \mathrm{~m}^{-2}$ for the urchin Strongylocentrotus droebachiensis (individuals $>30 \mathrm{~mm}$ in test diameter), and about $3 \mathrm{~m}^{-2}$ for the sea star Asterias vulgaris. On 3 July 2003, we quantified ophiuroid spawning positions based on 231 O. aculeata and 86 O. robusta individuals observed in the field and on video recordings. During a $2 \mathrm{~h}$ dive in the morning (9:00 to 11:00 h) at Île au Marteau and a $1 \mathrm{~h}$ dive in the afternoon at Pointe Enragée (17:00 to 18:00 h), 1 diver (C. Dumont) filmed 50 min of the spawning event using a Sony handycam

Table 1. Locations, times and tidal conditions of the mass spawning events off the Mingan Islands, northern Gulf of St. Lawrence

\begin{tabular}{|lccc|}
\hline Location & Date & Time (h) & Tide \\
\hline Île aux & 6 July 1996 & 16:00-17:00 & High tide \\
Goélands & & & \\
Île aux & 2 July 1998 & $09: 30-11: 30$ & Late ebb tide \\
Goélands & & $16: 30-18: 00$ & Late flood tide \\
& & $18: 30-19: 15$ & High tide \\
Île au Marteau & 3 July 2003 & $09: 00-11: 00$ & Low tide \\
Pointe Enragée & 3 July 2003 & $17: 00-18: 00$ & Ebb tide \\
Pointe Enragée & 4 July 2003 & $10: 30-11: 10$ & Low tide \\
\hline
\end{tabular}


miniDV. Two other divers noted spawning behaviours and used 37 quadrats $(25 \times 25 \mathrm{~cm})$ to estimate proportions of male and female urchins releasing gametes.

Gonad indices for Asterias vulgaris (wet gonad mass as a percentage of total body wet mass) and Ophiopholis aculeata (wet gonad mass as a percentage of central disc wet mass) were calculated from samples of 10 to 15 adult individuals. A. vulgaris was sampled at 5 to $10 \mathrm{~m}$ depth at Île aux Goélands in 1998, and both species were sampled at about $6 \mathrm{~m}$ in depth at Pointe Enragée in 2003. Temperature records were obtained from thermographs at $8 \mathrm{~m}$ depth at Cap du Corbeau in 1996 and 1998 and at $6 \mathrm{~m}$ at Pointe Enragée in 2003.

\section{RESULTS}

\section{Mass spawning events}

We observed the first mass spawning on 6 July 1996 during a $1 \mathrm{~h}$ dive along the eastern side of Île aux Goélands (Table 1). Nearly all observed individuals of the sea star Asterias vulgaris and the ophiuroid Ophiopholis aculeata were releasing gametes.

Mass spawnings were again observed during 1 morning and 2 afternoon dives on 2 July 1998 (Table 1). These observations were also made along the eastern side of Île aux Goélands. During the morning dive (9:30 to $11: 30$ h), only Asterias vulgaris was spawning. At one point at the beginning of the dive, we noted that 12 out of the visible $20 \mathrm{~A}$. vulgaris individuals were spawning and a similar proportion appeared to be spawning as we continued along the edge of a bedrock platform.

At the beginning of the first dive in the afternoon (16:30 h), spawning Asterias vulgaris were common but the proportion of individuals spawning increased during the dive. We estimated that at least $80 \%$ were spawning at 17:20 h. At one point, we moved to shallower water $(2 \mathrm{~m})$ where $A$. vulgaris was less abundant, and here too most individuals were spawning. At 17:30 h during the same dive, we further observed the onset of a mass spawning by the ophiuroid Ophiopholis aculeata. At the end of the dive (18:00 h), at least 50\% of the individuals were spawning. During the final dive (18:30 to 19:15 h), O. aculeata was no longer spawning. All individuals had returned to their crevices. However, at least $40 \%$ of the Asterias vulgaris individuals were still spawning. These afternoon dives coincided with a moderate current during the latter part of the flood tide. At 18:00 $\mathrm{h}$, the water was turbid and suspended eggs were visible. Gonad size measurements for $A$. vulgaris individuals collected at Île aux Goélands showed a major drop between 26 June and 4 July (Fig. 2), likely due to the mass spawning we observed. The slight decrease during July and August probably represented reabsorption of residual gametes.

We were able to make extensive observations of mass spawnings by 4 echinoderms in 2003. We noted the first evidence of a major spawning during a $15 \mathrm{~min}$ evening dive on 2 July at Pointe Enragée, when about 50 male urchins (and no females) in one area of the urchin barrens were seen releasing gametes. We did not make further observations because of nightfall. The next morning (Table 1) we dived at Île au Marteau and observed mass spawnings of 3 species. Large

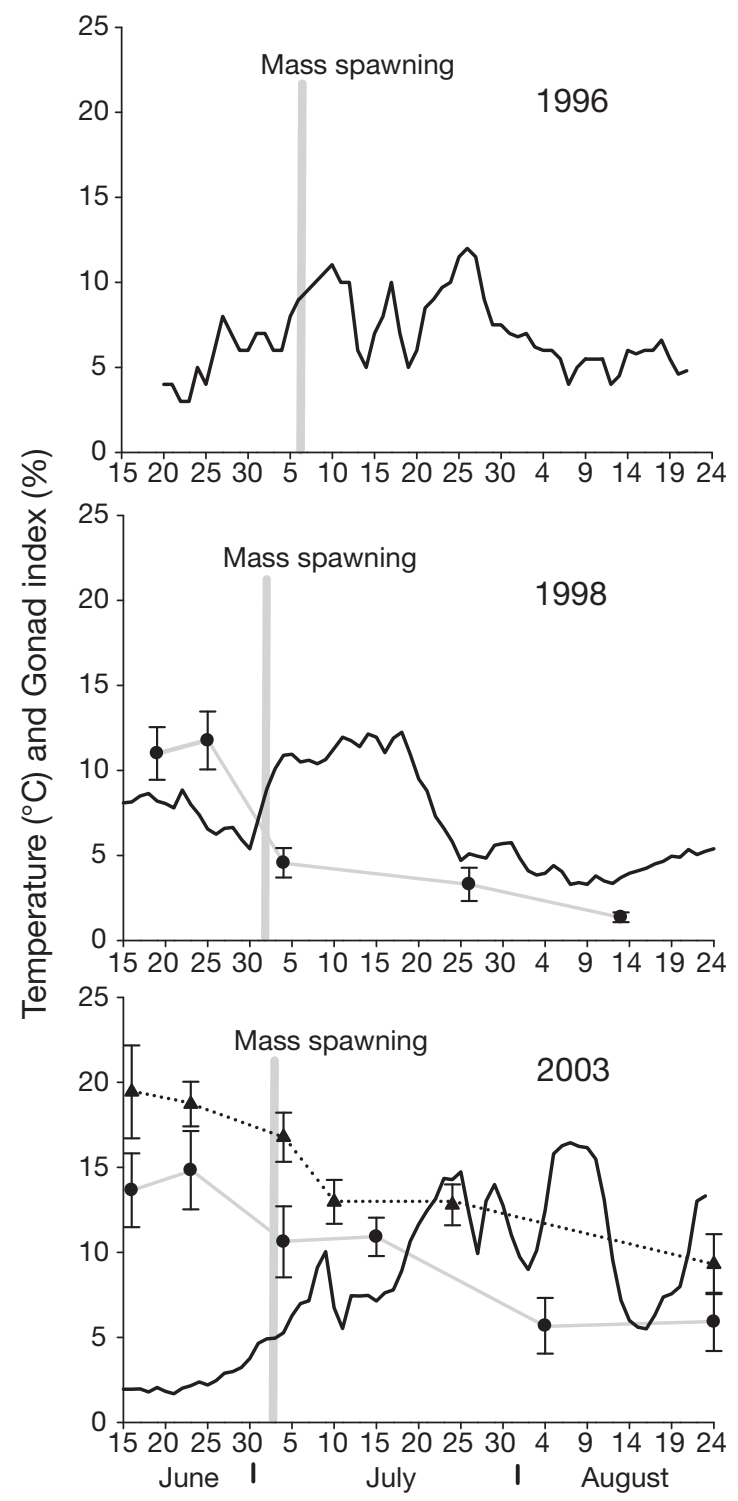

Fig. 2. Timing of mass spawning events (grey bar) off the Mingan Islands (northern Gulf of St. Lawrence) associated with the first major downwelling event each year as indicated by increasing water temperatures (-). Decreases in gonad indices of the sea star Asterias vulgaris (•) and the ophiuroid Ophiopholis aculeata ( $\mathbf{\Lambda})$ also showed when gamete release occurred. Vertical bars are \pm SE $(n=10-15)$ 
numbers of the urchin Strongylocentrotus droebachiensis were spawning as we began to dive at 09:00 $\mathrm{h}$ and continued to spawn for slightly more than $1 \mathrm{~h}$. The ophiuroid Ophiura robusta began spawning at about 10:00 $\mathrm{h}$ and spawned massively for about $30 \mathrm{~min}$. The ophiuroid Ophiopholis aculeata started spawning at about $10: 40 \mathrm{~h}$ (5 to $10 \mathrm{~min}$ after $O$. robusta had stopped) and spawned massively for about $20 \mathrm{~min}$. No spawning echinoderms were observed when we dived a short time later (11:30 to $12: 10 \mathrm{~h}$ ) at Pointe Enragée, located about $3 \mathrm{~km}$ from Île au Marteau (Fig. 1). However, during a second dive at Pointe Enragée in the afternoon $(17: 00$ to $18: 00 \mathrm{~h})$, we observed a mass spawning by $O$. robusta followed by mass spawning by $O$. aculeata. During a dive at Pointe Enragée the following morning (10:30 to $11: 10 \mathrm{~h}_{\text {; }}$ 4 July), we again observed spawning by $O$. robusta, but in lower numbers.

We observed only about 10 Asterias vulgaris individuals spawning on 3 July (île au Marteau); however, 3 were in spawning position during one dive on 2 July (Pointe Enragée), 5 during a dive on 6 July (île au Marteau), and 35 during a dive on 7 July (Île au Marteau). Gonad size measurements from the samples of A. vulgaris from Pointe Enragée in 2003 showed only a moderate decrease in gonad size between late June and early July, but low values approaching those observed on 4 July 1998 were encountered only much later (Fig. 2). This suggests that $A$. vulgaris spawned additionally in late July. The gonad measurements for Ophiopholis aculeata dropped markedly by 10 July. It is likely that the further decrease recorded between late July and late August represented reabsorption of gonad tissues.

Finally, we observed spawning by small numbers of several other invertebrates in early July 2003: 5 individuals of Mya truncata and 5 of Hiatella arctica on 2 July, and 3 Acmaea testudinalis and 1 Nereis virens on 3 July.

\section{Environmental factors}

The various spawning events occurred at different parts of the tidal cycle (Table 1). Spawning events also varied with the lunar cycle, from $1 \mathrm{~d}$ before the last quarter moon (6 July 1996) to 1 or $3 \mathrm{~d}$ before the first quarter moon (2 July 1998 and 3 July 2003, respectively). In all years, the mass spawnings coincided with the first major increase in seawater temperatures (Fig. 2). All of the spawnings occurred during periods of weak to moderate currents. We noted that the filaments of gametes did not fall to the bottom, as seen under laboratory conditions, but gradually dispersed with water movements. Our observations and the vi- deo recordings further illustrated that dispersal and mixing of gametes were clearly enhanced by the back and forth water movement caused by waves.

\section{Spawning behaviours}

Individuals of the ophiuroids Ophiopholis aculeata and Ophiura robusta are almost always found with the central disc tucked into the pits in the calcareous rock that forms the Mingan Islands (arms are extended into the water column to feed; Fig. 3A). However, as spawning began they rapidly abandoned their crevices for elevated surfaces (see Supplementary Video, available at: www.int-res.com/articles/suppl/m361p161_app/). Some even crawled onto the upper surfaces of macroalgae and predators (the sea urchin Strongylocentrotus droebachiensis and the sea star Asterias vulgaris; Fig. 3B). Most spawned standing on their arm tips, presumably to maximally elevate the disc from which gametes were released. During 2003, about $40 \%$ of $O$. aculeata and $25 \%$ of $O$. robusta spawned alone. Of the O. aculeata that spawned alone, $70 \%$ lifted one arm vertically. Many ophiuroids pseudocopulated (Fig. 3C,D; Video), a behaviour in which an individual approached and wrapped its arms around the central disc of a spawning member of the opposite sex $(40 \%$ of $O$. aculeata and $25 \%$ of $O$. robusta) or in which 3 to 5 individuals wrapped their arms around one another $(20 \%$ of $O$. aculeata and $50 \%$ of $O$. robusta).

Sea stars also sought elevated surfaces to spawn (Fig. 3E). Some even climbed onto the upper surfaces of blades of the kelp Agarum clathratum (9 instances in 1998), and substantial portions of the ambulacral surfaces were not attached to the kelp. This was surprising, as sea stars normally do not crawl over kelp blades. Most spawned alone, with the disc raised as high as possible (with only arm tips in contact with the bottom), although 2 large individuals (22 and $26 \mathrm{~cm}$ in diameter, respectively, compared to 12 to $18 \mathrm{~cm}$ for most other individuals) spawned without raising the central disc. Also, in 1998 aggregations of spawning sea stars crawling over one another were common (usually 3 to 5 individuals but in 3 instances 10 to 12 ) and 1 spawning aggregation ( 2 males and 1 female) was seen in 2003 (last sequence of the Video). The movements of the sea stars were much faster than their normal slow behaviour (one usually has to watch attentively over several minutes to notice movement).

In the case of the urchin, only $18 \%$ of the individuals at Île au Marteau on 3 July 2003 were spawning $\left(10\right.$ spawners $\left.\mathrm{m}^{-2}\right)$ and $80 \%$ of these were males. We only saw 2 instances of individuals approaching one another (Fig. 3F). For both sexes, gametes accumulated on the aboral surface before slowly dispersing into the water column (see Video). 

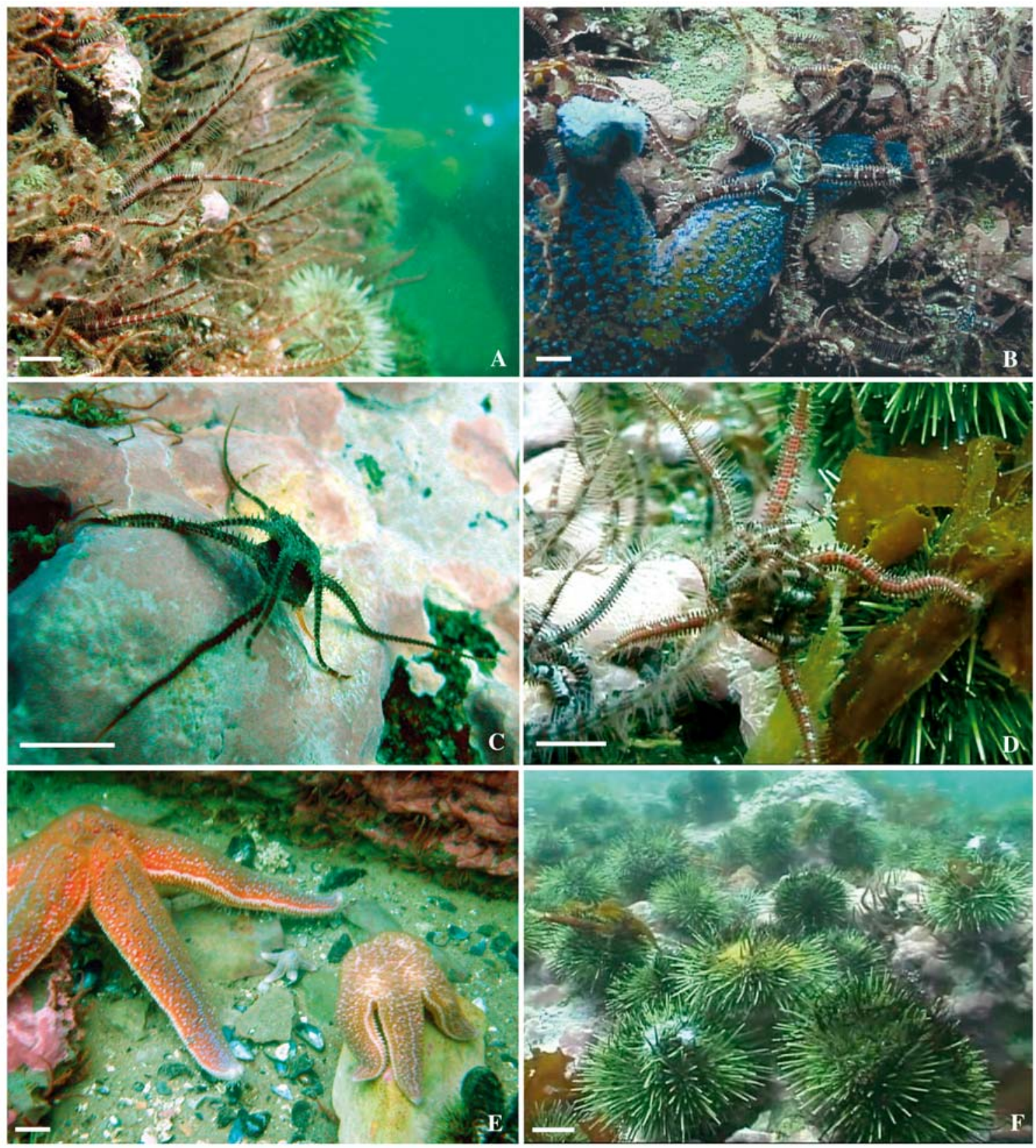

Fig. 3. Echinoderms spawning in 2003 off the Mingan Islands, eastern Canada. (A) Non-spawning ophiuroids Ophiopholis aculeata, with the central discs tucked into pits in a calcareous rock wall and arms extended to feed. (B) Male ophiuroid $O$. aculeata that has crawled onto its predator, the sea star Asterias vulgaris, to spawn. (C) Pseudocopulation of 2 ophiuroids Ophiura robusta, with the central disks held oral-to-aboral surface, and (D) pseudocopulating by 3 ophuroids $O$. aculeata, central disks held together. (E) A sea star, A. vulgaris (left), that is moving rapidly towards another sea star (right) in spawning position. (F) Spawning female sea urchin Strongylocentrotus droebachiensis (behind) that is moving closer to a spawning male (front left). Scale bars $=1 \mathrm{~cm}$. Photo credit: C. P. Dumont

\section{DISCUSSION}

All of the spawnings coincided with sharp increases in sea temperature caused by downwelling, the incursion of warm surface waters from the Gulf towards the coast (Fig. 1). This downwelling occurs when there is an easing of the upwelling of cold waters in the region (Lefaivre 1995). Upwelling conditions, driven by wind and tidal currents conditions, predominate during the spring and summer in the Mingan Islands.

The coincidence of spawning with sharply increasing sea temperatures does not necessarily mean that 
rising temperatures triggered spawning, as many factors changed with the entry of the new water mass into the Mingan Islands. Indeed, the late spawning of urchins in 2003 was more likely triggered by phytoplankton in the new water mass (Himmelman 1975, Starr et al. 1990, Gaudette et al. 2006). The sequential spawnings observed for different species in 2003 (Strongylocentrotus droebachiensis followed by Ophiura robusta and then Ophiopholis aculeata) could mean either that each species was triggered to spawn by a different environmental signal or by different thresholds to the same signal.

In each year, the mass spawnings we observed took place at the onset of the first major downwelling event. Recognizing this association after reviewing our observations from 1996 and 1998 allowed us to prepare for better documentation of spawning events in 2003. We had expected the first major downwelling (and associated spawning) to occur between late June and the first weeks of July. In the Baie des Chaleurs, southern Gulf of St. Lawrence, spawning by the giant scallop Placopecten magellanicus also coincides with a sudden temperature rise caused by downwelling (Bonardelli et al. 1996). Spawning is progressively delayed going up the bay because downwelling events first develop in the outer bay and then propagate into the bay. However, the scallop's spawning does not correspond to first major downwelling event, as its gonads only mature during the summer. The species we studied had attained gonad maturity in late winter, and thus were in condition to spawn at the time of the first downwelling event.

Strongly synchronous spawning by large numbers of individuals should favour both fertilization success and outbreeding. The degree of spawning synchrony varied for the different species. It was most striking for the ophiuroids Ophiopholis aculeata and Ophiura robusta as spawning appeared to have occurred within 30 to 40 min in any given spawning episode. This spawning duration could have depleted the gonads, given their small body size (the central disc measures $<20 \mathrm{~mm}$ for $O$. aculeata and $<5 \mathrm{~mm}$ for $O$. robusta) and the rate at which gametes were seen streaming from the bursal openings. It should take much longer to evacuate gametes from sea stars as they are much larger and the observed rate of gamete release was not markedly greater than for ophiuroids. Our field observations suggested that spawning was a longer process for Asterias vulgaris. We encountered individuals spawning on several days each year, and even during the major spawning at Île aux Goélands on 2 July 1998, individuals were spawning in the morning and the afternoon.

In the species we studied, selection over evolutionary time has likely resulted in adapting an environ- mental change associated with downwelling as a spawning cue. In our study region, the first major downwelling likely represents the strongest change in water conditions during the year. Thus, it could have been selected as a signal for synchronous spawning to enhance fertilization success. Spawning during a downwelling event further means that embryos and larvae are produced in warm surface waters. This could favour both more rapid growth (due to the higher temperatures and greater food abundance) and reduced losses from predators (as more rapid development means a shorter period of exposure to predators in the water column).

Spawning individuals clearly exhibited behaviours that would help bring male and female gametes together (Fig. 3, Video). The ophiuroids Ophiopholis aculeata and Ophiura robusta and the sea star Asterias vulgaris rapidly crawled onto elevated surfaces to spawn. Further, the most common spawning position was standing on the arm tips to raise the central disk, and thus the gonopores, as high as possible. Both behaviours would increase suspension and mixing of gametes. The lifting of one arm during spawning, as observed for O. aculeata, would likely increase turbulence.

Pseudocopulation was also employed by the sea star and the 2 ophiuroids to bring male and female gametes together. The movement together of sea stars to pseudocopulate was only documented for 1 small group in 2003 (Video). In contrast, we observed many instances of ophiuroids coming together to pseudocopulate in all 3 years. Couples formed when an individual moved towards an individual that was spawning alone on its arm tips. The approaching individual placed its central disc next to that of the spawning individual (either oral to oral or oral to aboral surface) and then wrapped its arms around the disc of the first individual. Often a third individual was attracted to the spawning pair and wrapped its arms around the first two. Many times the sex of the pseudocopulating individuals was evident from the type of gametes being released. The first individual to spawn was always a male and was then joined by a female. This would run counter to the laboratory observations on 2 ophiuroid species by Soong et al. (2005). They found that an ovarian homogenate would stimulate males to spawn, but a testicular homogenate would not stimulate females to spawn. The urchins did not pseudocopulate, and there were only 2 instances where spawning individuals appeared to be moving together. Several times during the urchin spawning in 2003, we noted that when an isolated female started to spawn, nearby $(<0.5 \mathrm{~m})$ non-spawning males followed by releasing sperm. This suggested that although males generally initiate spawning, gametes release in less responsive males can be triggered by detection of spawning females. 
Pseudocopulation has previously been reported for 2 subtropical sea stars Archaster typicus and A. angulatus (Mortensen 1931, Run et al. 1988) as well as the Antarctic sea star Neosmilaster georgianus (Slattery \& Bosch 1993). Male and female A. typicus form pairs about 2 mo prior to spawning (males climb onto the aboral surface of a female). The laboratory observations of Run et al. (1988) show that the spawning event within a pair is initiated by the female; the male only releases sperm when eggs are detected. $N$. georgianus is a brooding asteroid that probably reproduces throughout the year, and its pseudocupulation behaviour involves one to several males climbing onto a reproductively active female for a period of minutes to hours before spawning. The pseudocopulatory behaviour of $A$. vulgaris contrasts with that of the above asteroids as it involves groups of spawning individuals coming together and rapidly crawling over one another during an epidemic spawning event. Our study provides the first report of the short-term movement of male and female ophiuroids together to spawn. Nevertheless, pseudocopulation may occur in a number of dimorphic ophiuroid species, in which small males are permanently attached to the central disc of females (Hendler 1991, Tominaga et al. 2004).

All of the spawning events we observed occurred under low-flow conditions, which suggests that the dilution of gametes would be less rapid and less detrimental to fertilization success than previously thought. Also, gametes were released in viscous fluids that first stayed together as strands (in the case of ophiuroids, see Video) or clung to the aboral surfaces (in the case of urchins, see Video). The experiments of Yund \& Meidel (2003) with urchins in a flume indicate that the retention of eggs near spawning females enhances fertilization success. They found that about half of the eggs were fertilized prior to being advected from the aboral surface. Further fertilization likely occurred in eddies downstream from the females.

Many aspects of the spawnings we documented appear to reflect strategies for attaining the high densities of gametes required for fertilization success. These included the abrupt and synchronous gamete release by many individuals, spawning at low flow velocities, and individuals coming together to pseudocopulate. However, 2 of the behaviours of the ophiuroids and the asteroid, i.e. moving to high positions to spawning, and raising the central disc while spawning, present a paradox, since these behaviours should favour gamete dilution. Similar behaviours are reported for other ophiuroids and asteroids as well as other invertebrates (Breen \& Adkins 1980, McEuen 1988, Hendler 1991, Babcock et al. 1992, Hagman \& Vize 2003). These behaviours indicate that although high gamete densities are important, a degree of mix- ing of gametes with seawater is required to bring eggs and sperm into contact. For most species, releasing gametes near the bottom (especially within the boundary layer) could result in the gametes falling to the bottom and being wasted.

The strong spawning synchrony (especially in ophiuroids) and striking spawning behaviours we observed should have greatly enhance fertilization success. Such observations of spawning events in nature are rare but are needed to validate or refute fertilization models and assess the relevant factors to better simulate spawning events.

Acknowledgements. We are grateful to J. Raymond, M. Giasson, J. Gaudette, T. Gosselin, F. Pernet, M. Guay, P. Gagnon, P. Gauthier, I. Deschênes, P. Grondin, F. Praira and M. Thompson for their aid in making these observations. We are thankful to M. Russell, H. Guderley, R. Wahle, L. Johnson, J. McNeil and J. Larochelle for providing comments of an early draft of the paper. Also, suggestions by the editor, D. Levitan, and discussions with Australian colleagues, G. Mundy and M. Byrne, aided us in broadening our discussion of spawning behaviours. This study was funded by a Discovery Grant from National Sciences and Engineering Research Council of Canada to J.H.H.

\section{LITERATURE CITED}

Babcock R, Mundy C, Keesing J, Oliver J (1992) Predictable and unpredictable spawning events: in situ behavioural data from free-spawning coral reef invertebrates. Invertebr Reprod Dev 22:213-227

Bonardelli JC, Himmelman JH, Drinkwater K (1996) Relation of spawning of the giant scallop, Placopecten magellanicus, to temperature fluctuations during downwelling events. Mar Biol 124:637-649

Breen PA, Adkins BE (1980) Spawning in a British Columbia populations of northern abalone, Haliotis kamtschatkana. Veliger 23:177-179

Caspers H (1984) Spawning periodicity and habitat of the palolo worm Eunice viridis (Polychaeta: Eunicidae) in the Samoan Islands. Mar Biol 79:229-236

Denny MW, Nelson EK, Mead KS (2002) Revised estimates of the effects of turbulence on fertilization in the purple sea urchin, Strongylocentrotus purpuratus. Biol Bull 203: 275-277

Drolet D, Himmelman JH, Rochette R (2004a) Use of refuges by the ophiuroid Ophiopholis aculeata: contrasting effects of substratum complexity on predation risk from two predators. Mar Ecol Prog Ser 284:173-183

Drolet D, Himmelman JH, Rochette R (2004b) Effect of light and substratum complexity on microhabitat selection and activity of the ophiuroid Ophiopholis aculeata. J Exp Mar Biol Ecol 313:139-154

> Dumont CP, Himmelman JH, Russell MP (2006) Daily movement of the sea urchin Strongylocentrotus droebachiensis in different subtidal habitats in eastern Canada. Mar Ecol Prog Ser 317:87-99

$>$ Dumont CP, Himmelman JH, Robinson SMC (2007a) Movement pattern of the sea urchin Strongylocentrotus droebachiensis. J Exp Mar Biol Ecol 340:80-89

> Dumont CP, Drolet D, Deschênes I, Himmelman JH (2007b) Multiple factors explain the covering behaviour in the green sea urchin Strongylocentrotus droebachiensis. Anim Behav 73:979-986 
Gaudette J, Wahle RA, Himmelman JH (2006) Spawning events in small and large populations of the green sea urchin Strongylocentrotus droebachiensis as recorded using fertilization assays. Limnol Oceanogr 51:1485-1496

Gaymer CF, Himmelman JH, Johnson LE (2001) Distribution and feeding ecology of the seastars Leptasterias polaris and Asterias vulgaris in the northern Gulf of St. Lawrence, Canada. J Mar Biol Assoc UK 81:827-843

Gaymer CF, Himmelman JH, Johnson LE (2002) Effect of intraand interspecific interactions on the feeding behavior of two subtidal seastars. Mar Ecol Prog Ser 232:149-162

Hagman DK, Vize PD (2003) Mass spawning by two brittle star species, Ophioderma rubicundum and O. squamosissimum (Echinodermata: Ophiuroidea), at the Flower Garden Banks, Gulf of Mexico. Bull Mar Sci 72:871-876

Hamel JF, Mercier A (1996) Gamete dispersion and fertilisation success of the sea cucumber Cucumaria frondosa. SPC Beche-de-mer Info Bull 8:34-40

Harrison PL, Babcock RC, Bull GD, Oliver JK, Wallace CC, Willis BL (1984) Mass spawning in tropical reef corals. Science 223:1186-1189

Hendler G (1991) Ophiuroida. In: Giese AC, Pearse JS, Pearse VB (eds) Reproduction in marine invertebrates, Vol. 6, Echinoderms and lophorates. Boxwood Press, Pacific Grove, CA, p 355-511

Himmelman JH (1975) Phytoplankton as a stimulus for spawning in three marine invertebrates. J Exp Mar Biol Ecol 20:199-214

Himmelman JH (1999) Spawning, marine invertebrates. In: Knobil E, Neill JD (eds) Encyclopedia of reproduction, Vol 4. Academic Press, London, p 524-533

Kubota H (1980) Synchronization of spawning in the crinoid, Comanthus japonica. In: Clark WH, Adams TS (eds) Advances in invertebrate reproduction. Elsevier North Holland, Amsterdam, p 69-74

Lefaivre D (1995) Les eaux froides dans la région de l'archipel Mingan. Nat Can 119:74-75

Levitan DR, Petersen C (1995) Sperm limitation in the sea. Trends Ecol Evol 10:228-231

McEuen FS (1988) Spawning behaviors of northeast Pacific sea cucumbers (Holothuroidea: Echinodermata). Mar Biol 98:565-585

Editorial responsibility: Don Levitan,

Tallahassee, Florida, USA
Minchin D (1987) Sea-water temperature and spawning behaviour in the seastar Marthasterias glacialis. Mar Biol 95:139-143

Minchin D (1992) Multiple species, mass spawning events in an Irish sea lough: the effect of temperatures on spawning and recruitment of invertebrates. Invertebr Reprod Dev $22: 229-238$

Mortensen RH (1931) Contributions to the study of the development and larval forms of echinoderms. I-II. K Dan Vidensk Selsk Skr Naturv Math 4:1-39

> Raymond JF, Himmelman JH, Guderley HE (2007) Biochemical content, energy composition and reproductive effort in the broadcasting sea star Asterias vulgaris over the spawning period. J Exp Mar Biol Ecol 341:32-44

Run JQ, Chen CP, Chang KH, Chia FS (1988) Mating behaviour and reproductive cycle of Archaster typicus (Echinodermata: Asteroidea). Mar Biol 99:247-253

Sewell MA, Levitan DR (1992) Fertilization success in a natural spawning of the dendrochirote sea cucumber $\mathrm{Cucu}$ maria miniata. Bull Mar Sci 51:161-166

Slattery M, Bosch I (1993) Mating behavior of a brooding antarctic asteroid, Neosmilaster georgianus. Invertebr Reprod Dev 24:97-102

Soong K, Chang D, Chao SM (2005) Presence of spawninducing pheromones in two brittle stars (Echinodermata: Ophiuroidea). Mar Ecol Prog Ser 292:195-201

Starr M, Himmelman JH, Therriault JC (1990) Marine invertebrate spawning induced by phytoplankton. Science 247: 1071-1074

Thorson G (1946) Reproduction and larval development of Danish marine bottom invertebrates. Medd Kommn Danm Fisk Havunder Ser 4 Plankton 4:1-553

Tominaga H, Nakamura S, Komatsu M (2004) Reproduction and development of the conspicuously dimorphic brittle star Ophiodaphne formata (Ophiuroidea). Biol Bull 206: 25-34

Yund PO (2000) How severe is sperm limitation in natural populations of marine free-spawners? Trends Ecol Evol 15:10-13

Yund PO, Meidel SK (2003) Sea urchin spawning in benthic boundary layers: Are eggs fertilized before advecting away from females? Limnol Oceanogr 48:795-801

Submitted: May 17, 2007; Accepted: January 22, 2008 Proofs received from author(s): May 14, 2008 